group of metallic Xylocopa with dark face in the male, represented by librocedri, arizonensis, and californica, belongs to the Pacific coast and the arid southwest, and is not related to the species of tropical Mexico and Central America. A related but distinct group, with light face in the male, is that of $X$. virginica and texana, with the little-known amblardi, said to occur in California. A marked feature common to both of these groups is the triangular area with strongly pectinate border on sixth abdominal segment of female. It is also to be noted that there exists a variety of arizonensis in which the clypeus of the male has a creamcolored spot (Entom. News, Nov., 1907, p. 395). The mandibles of $X$. arizonensis, librocedri, and virginica are bidentate in the female, not tridentate as in the European $X$. violacea. The association with Librocedrus (Heyderia) decurrens may be accidental; but it is interesting to find a member of what appears to be a rather old type of North American bees connected with a plant-genus which we know to be an ancient and now waning member of the flora.

Type, Cat. No. 18460, U. S. Nat. Mus.

\title{
NEW MICROLEPIDOPTERA FROM HAWAII
}

\section{By AUGUST BUSCK}

Mr. Otto H. Swezey, of the Hawaiian Sugar Planters' Association Experiment Station, has recently sent to the U. S. National Museum a third large contribution to the knowledge of Hawaiian Microlepidoptera, consisting of 50 bred species, each in liberal and well-mounted series. Most of these are known species or cotypes of new forms described by Mr. Swezey, but the biological facts are all new, and Mr. Swezey will himself give a complete account of these. He has asked me to determine and describe the following new species.

\section{Platyptilia lantana, new species.}

Labial palpi short, dark fuscous, irrorated with yellowish white and with apex of second and of third joint yellowish white. Face and head fuscous. Face without projecting cone. Antennæ dark brown dotted with light yellow. Thorax fuscous with posterior edge broadly white. Forewings cleft to apical two-thirds; segments broad, termen of the first with one of the second with two sinuations; ground color whitish ochre- 
ous strongly mottled and irrorated with dark fuscous and blackish scales, which form an ill-defined dark shade on basal half of dorsal edge, a large, ill-defined dark area at costal third extending attenuated along costa nearly to base, and a broad, dark fascia across the outer ends of the lobes; this fascia is externally edged with white scales and the narrow apical strip beyond is light ochreous with a dark brown sinuated line at the base of the cilia ; small black scale tufts beyond the edge on the middle and at apical third of dorsum. Hindwings dark fuscous with ochreous cilia ; third lobe with a large black scale tuft just before apex and a few scattered projecting black scales along the entire dorsal edge. Abdomen ochreous fuscous, each joint tipped with white posteriorly; fourth joint shaded with black. Legs fuscous, tarsal joints with broad white annulations.

Alar expanse, $11 \mathrm{~mm}$.

Habitat: Honolulu, Oahu, Hawaiian Islands.

Type, Cat. No. 18429, U. S. Nat. Mus.

Mr. Swezey informs me that this species was introduced purposely from America into Hawaï some 12 years ago by Mr. Koebele, along with 7 other species of Lantana insects, and it should thus undoubtedly be credited to the fauna of Central America, though I have no actual specimen from there.

Petrochroa, new genus (family Cygnodiidæ).

Type, $P$. swezeyi Busck.

Labial palpi long, curved, nearly smooth ; both joints slightly thickened and roughened in front; terminal joint nearly as long as second, pointed. Antennæ three-fourths serrated; basal joint with strong pecten. Face and head smooth. Forewings smooth, elongate ovate, apex somewhat produced, pointed; 12 veins; 7 and 8 out of $6 ; 7$ to costa ; rest separate; $2,3,4$, and 5 nearly equidistant; $1 b$ furcate at base. Hindwings more than half the width of the forewings, pointed; 6 and 7 stalked, enclosing apex; rest of the veins separate; 8 reaching to apical fourth; space between 7 and 8 large and upper cell vein weak; internal vein to base of $6+7$ strong; in the males the venation in both wings may often be distorted; in the forewing vein 7 may be nearly or quite obsolete; in the hindwings large male sense tufts dislocate the veins; female frenulum consisting of three spines. Posterior tibia hairy above. 
The genus is allied to Coelopoeta Walsingham, but differs in having vein 5 of the forewing free and in having the cell in the hindwings closed and veins 2 to 5 separate.

\section{Petrochroa swezeyi, new species.}

Labial palpi light ochreous with tip of terminal joint black. Face, head, and thorax dusky brownish ochreous, with a strong iridescent sheen. Antennæ dark brown, sprinkled with light ochreous on the terminal joints. Forewings dark brownish fuscous with an ill-defined, whitish ochreous costal spot at apical third faintly connected across the wing with an opposite similar dorsal spot; cilia lighter ochreous fuscous. Hindwings uniformly light fuscous with concolorous cilia; in the males with a strong tuft of broad scale-like hairs at the base of costa. Abdomen silvery fuscous. Legs dark brown with narrow light ochreous annulations on the tibiæ and on the tarsal joints.

Alar expanse, 7-8 mm.

Habitat: Kaimuki, Oahu, Hawaii.

Type, Cat. No. 18430, U. S. Nat. Mus.

Named in honor of the industrious collector, Mr. Otto H. Swezey, who bred this species from small cases found on rocks.

The cases are made of tough silk and completely covered with small particles of sand and rock, which give a dark reddish brown color to the specimen before me. The cases are $4.5 \mathrm{~mm}$. long and $2 \mathrm{~mm}$. broad, somewhat flattened and with a transverse slit in one end.

Petrochroa dimorpha, new species.

Labial palpi light ochreous, strongly shaded externally with black. Face and head light ochreous. Antennæ light ochreous, in the females annulated with dark brown through the entire length, in the males annulated with dark brown only on outer two-thirds; basal pecten long, black. Thorax light ochreous with dark brown patagia. Forewing dark brown on the costal two-thirds, light ochreous on the dorsal edge; a short, longitudinal, black streak a little before the middle of the wing on the border line of the two colors; a large, round, black spot at the end of the cell slightly edged with white scales. Cilia ochreous. Hindwings light silvery fuscous, with ochreous cilia; in the males with costal tuft of stiff hairs. Abdomen dark silvery fuscous above, ochreous on the underside. Male anal tufts large, ochreous. Legs straw-colored with black bars and annulations. 
Alar expanse, 9-10 mm.

Habitat: Honolulu, Hawaiian Islands.

Type, Cat. No. 18431, U. S. Nat. Mus.

A pretty little species which superficially reminds one of Aroga paraplutella Busck. The larva feeds, according to Mr. Swezey, in dead leaves and grass on the ground. Both this and the foregoing species come to lights at night.

\section{Batrachedra cuniculator, new species.}

Labial palpi light straw-colored with conspicuous, transverse, black spots exteriorly, one on the second joint, one at the base of terminal joint, and one below the tip. Face and head light yellow. Antennæ darker ochreous with narrow black annulations. Thorax light ochreous. Forewings light ochreous, somewhat darker toward the tip, minutely dusted with black; a conspicuous black dash on the cell, another obliquely before it on the fold, and a third at the end of the cell; cilia straw-yellow. Hindwing light ochreous fuscous with yellow cilia. Abdomen light yellow ; on the dorsal side of first and second joints is a peculiar, flattened, short-scaled whitish area surrounded by longer scales; this is more noticeable in the females than in the males. Legs light ochreous.

Alar expanse, 9-10 mm.

Habitat: Kewalo, Honolulu, Hawaiian Islands. July.

Type, Cat. No. 18432, U. S. Nat. Mus.

Bred by Mr. Swezey, who writes that it is a leaf-miner in sedges, Scirpus maritimus, in the swamps near the coast; it also bores in the stems of Cyperus lavigatus, which is leafless and has cylindrical stems resembling rushes. Mr. Swezey considers this moth a recent introduction into Hawaii; it had not been noticed until about a year ago.

Acrolepia nothocestri, new species.

Labial palpi blackish brown, with narrow white annulations, two on each joint, and with white tips. Maxillary palpi yellowish white. Face yellowish white. Head bright yellow sparsely sprinkled with black. Antennæ light yellow with narrow deep black annulations. Thorax dark greenish yellow strongly overlaid with black; patagia yellow with blackish fuscous base. Forewing bright canary yellow, strongly transversely reticulated with black; the black scaling is emphasized in three large, ill-defined costal blotches, which reach halfway across the wing, one at basal fourth, one just before the middle of the wing, and one 
beyond the middle; the last one is the most prominent, but all are vague ; on the middle of the wing near base is a small round white spot, on the middle of the dorsal edge is a large, transverse, kidney-shaped white spot; at basal third is a similar, somewhat smaller, dorsal white spot, but not touching the edge; at the end of the cell is a round white spot; all the white spots are more or less edged with black; apical part of the wing beyond the cell is yellow without the black reticulation, but with two blackish, ill-defined costal spots, the outer of which is diffused into a large triangular dark shade, reaching halfway across the wing. Cilia yellowish white with conspicuous blackish brown pencils alternating with broader white intermediate spaces. Hindwing dark fuscous with silvery fuscous costal edge and with apical cilia whitish. Abdomen brownish fuscous above with first joint silvery and with light yellow underside and anal tuft. Legs light yellowish fuscous, tarsal joints with broad black annulations.

Alar expanse, $12 \mathrm{~mm}$.

Habitat: Olympus, Oahu, Hawaiian Islands.

Type, Cat. No. 18433, U. S. Nat. Mus.

This conspicuously colored species is a leaf-miner on Nothocestrum. (O. H. Swezey.)

\section{A NEW SATURNIAN FROM MEXICO}

(Lepidoptera, Saturniida)

By HARRISON G. DYAR

Copaxa mannana, new species.

Male: Fore wing falcate; antennæ fully doubly bipectinate, the branches equal. Brown; costa and collar gray; fore wing with a slitshaped hyaline discal patch; lines faint, purple, the inner irregular, the outer oblique to costa before apex, faintly doubled within. Hind wing rosy red from costa to over cell, except margin; a large discal ocellus, black, with inner blue powdery crescent, broadly buff-yellow ringed, then a black ring; two mesial lines, fading out in the pink area, the outer crenulate. Expanse, $95 \mathrm{~mm}$.

Female: Fore wing quadrate, the outer margin straight; antennæ shortly singly bipectinate; yellow, irrorate with gray; costa and collar gray; discal hyaline slit small; lines as in the male, but distinct and 


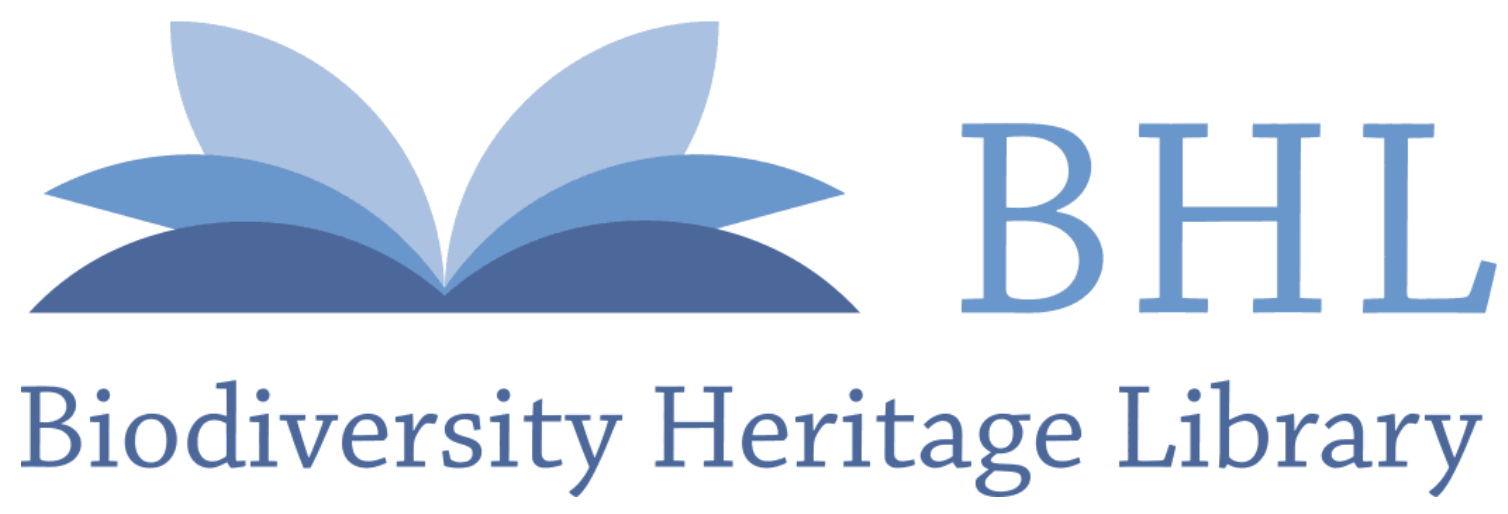

1914. "New Microlepidoptera from Hawaii." Insecutor inscitiae menstruus 2 , 103-107. https://doi.org/10.5962/bhl.part.9586.

View This Item Online: https://www.biodiversitylibrary.org/item/36243

DOI: https://doi.org/10.5962/bhl.part.9586

Permalink: $\underline{\text { https://www.biodiversitylibrary.org/partpdf/9586 }}$

\section{Holding Institution}

Smithsonian Libraries

\section{Sponsored by}

Smithsonian

\section{Copyright \& Reuse}

Copyright Status: NOT_IN_COPYRIGHT

This document was created from content at the Biodiversity Heritage Library, the world's largest open access digital library for biodiversity literature and archives. Visit BHL at https://www.biodiversitylibrary.org. 